\title{
12 Adapting the Nordic welfare state model to the challenges of automation
}

\author{
Heikki Hiilamo
}

The inclusive Nordic welfare model has facilitated economic growth, stable business environments and excellent living conditions as demonstrated by a number of scholars. ${ }^{1}$ The Nordic 'happy democracies' have been characterised by consensual decision-making procedures, corporatism, relatively high voter turnout, wide representation of various social groups, active membership in social organisations and remarkable levels of both institutional and social trust. These qualities have contributed to the development of exceptionally strong public institutions, which in turn are justifiably connected to remarkable social outcomes in terms of well-being. However, as all investment prospectuses for private financial investors tend to emphasise, past performance is no guarantee of future results. The Nordic model was born under the lucky stars of regulated financial markets. It seems to have survived the earlier challenges of economic globalisation, but what will happen in the future and what kind of changes are to be expected if the model is to live up to its promise of producing equitable outcomes? From the start, a key feature of the inclusive Nordic model has been a high labour force participation rate. During the last 25 years the countries have shied away from the target of full employment but still aim to sustain a high rate of employment. Will it be possible to sustain this goal in the future?

Ever since the seminal study by C. B. Frey and M. A. Osbourne, ${ }^{2}$ there has been a lively debate on the future of work (see further discussion in the chapter by Holmén). The primary issue discussed in these debates is the expected impact of technological change, which includes broad and vague concepts such as automation, robotisation, ever-increasing computing power, Big Data, the penetration of the Internet, the Internet-of-Things, online platforms and artificial intelligence. Irrespective of the term used, one school of thought claims that machines will displace human labour - not just blue-collar tasks but white-collar ones as well - which will consequently result in labour market disruptions, while another school emphasises job polarisation in terms of both wages and employment vulnerability between routine middle-skilled workers and non-routine low-skilled and high-skilled workers. The debate has focused mainly on the role of technology, while other factors, such as societal institutions, have gained less attention. At present, the question of how to find meaningful employment for those at the margins of the labour market has urgent 
relevance throughout the Western world. As globalisation and technology are feared to eliminate more jobs, an increasing number of people may be unable to make ends meet with earnings from employment.

According to Pulkka, the expected effects of technological changes on future labour markets can be studied with two possible trajectories. With reference to effects of previous technology-induced disruptions, the 'this time is different' scenario suggests that progression in digital technologies and artificial intelligence is exponential and stable. Therefore, it is difficult to foresee the dynamics of the new demand for labour, harder for current workers to adjust to it with education and almost impossible for educational institutions to provide future workers with the type of skills needed. The scenario implies that without a major overhaul in policies, the digital economy will cause mass unemployment in the short and long term. The biggest losers will be people with low education, but the highly-educated are also harmed. ${ }^{3}$

The opposing 'this time is no different' scenario maintains that in wake of technological changes people have always been able to re-educate themselves for new jobs and that technological change has always created new jobs. This Neo-Schumpeterian scenario acknowledges the fact that while technological change has destructive effects on labour markets, it also has positive effects. Technology changes people's lifestyles and creates a demand for jobs that do not exist today or that currently play a very minor role. However, even this view comes with the prediction that, depending on time lag effects, automation will lead to more evolution of job tasks and short-term unemployment. ${ }^{4}$

For both scenarios, the time lag effect between the displacement of tasks and the creation of new tasks (reinstatement effects) due to automation is an important factor. Daron Acemoglu and Pascual Restrepo highlight the fact that the degree of labour market disruption depends on new tasks and new skills:

New tasks tend to require new skills. But to the extent that the workforce does not possess those skills, the adjustment process will be hampered. Even more ominously, if the educational system is not up to providing those skills (and if we are not even aware of the types of new skills that will be required so as to enable investments in them), the adjustment will be greatly impeded. ${ }^{5}$

Another factor that has an effect on inequality deals with changes in skill premiums and the associated inequality in wages and employment security. Pulkka maintains that even in the best-case scenario, the expected effects of technological changes will increase uncertainty in the labour market, while in the worst case they may induce disruption to the paid employment model. ${ }^{6}$

From the social justice point of view of John Rawls, it can be argued that the situation of the worst-off in a society is a powerful indicator of how successful the entire society is. When it comes to two vulnerable groups, children and the elderly, the Nordic countries have exhibited very low levels of poverty. These achievements are closely related to extensive investments in the Nordic 
countries to ensure that all children have equal rights to participate in education, health care and so on, and that they should be entitled to the necessary nutrition and housing resources so they can take full advantage of these rights. As small and open economies, the Nordic countries are forced to adopt technology as capital investments to better compete in the global markets. A high rate of employment is needed to collect taxes for these public investments. Highly developed public institutions demand a high level of taxes. Therefore, the question of technologically induced unemployment is crucial for the fiscal sustainability of the Nordic model. ${ }^{7}$

The eradication of poverty is not merely a matter of expenditures and compensation. Rather, as illustrated by Jon Kvist et al., it is primarily a question of investing in human capital especially among children and the youth. Children and the youth will utilise the human capital when they enter the labour market. The unique feature of the Nordic model is that it capitalises on the promotion of human capital accumulation among the less privileged. That has also boosted intergenerational mobility, which allows all talents to be utilised for the benefit of the societies and their people. ${ }^{8}$

This chapter studies the agility of the Nordic welfare and labour market model to adapt to the expected challenges of technological change and the specific focus areas that ensure equality of labour market outcomes in the wake of automatisation. We pay attention to both challenges and solutions adopted in the Nordic countries. The focal point of the analysis is on three dimensions of the Nordic model: namely social trust, human capital investment and labour markets. In connection to human capital investment, there is a separate review of young people's situation (the NEET - Not in Education, Employment or Training - debate). The chapter on labour markets includes a review on the universal basic income debate. The discussion is based on a review of literature on the Nordic welfare state model and the budding literature in the field of technological change and the welfare state.

\section{Social trust}

A convincing body of literature demonstrates that the level of trust in a society has consequences for economic performance as well as for individual wellbeing. The fact that Nordic countries display a high degree of trust in all dimensions has deep historical roots. The state bureaucracies have functioned well since King Gustaf Vasa (1521-1560), founder of the Swedish Kingdom, paid special attention to the administration of his country. Swedish statesman Axel Oxenstierna (1583-1654) went to great lengths to develop the state bureaucracy in the Swedish Kingdom.

In contrast to many other countries, the state and the municipalities in Scandinavia grew to be strong and powerful enough not to be harnessed as mere vehicles of some particular interest. One indication of this is that in Scandinavia the word 'state' is often used synonymously with 'society'. The population records of the Swedish Kingdom kept mainly for military conscriptions created 
a basis for effective taxation, which in turn was a crucial precondition for the independence of the state vis-à-vis other societal actors, and later for the construction of the welfare state. ${ }^{9}$

Robert Putnam has identified two dimensions of social capital: bridging or inclusive, and bonding or exclusive social capital. These two dimensions create different kinds of solidarity. The bridging form of social capital generates broader identities (a broad usness) and brings larger sections of society together by unifying them, whereas bonding social capital pertains to specific, group-based solidarity. The bonding form of social capital generates closer ties. However, because of its in-group solidarity, it may create strong out-group antagonism. Welfare state functions are more than simply distribution: who gets what and how much. The institutional set-ups of welfare state policy programmes unify and divide people and social groups. ${ }^{10}$

Throughout its history, social policy has had bridging and bonding functions. In the Nordic countries, the emphasis has been on the bridging side the basic principle in social policy schemes has been universalism, as expressed through people's insurances and the public education system. The policy goal of full employment and the solidarity enforced through a collective bargaining system have emphasised the bridging function of social capital. ${ }^{11}$ However, the balance may shift towards the bonding side of social capital if technological change increases differences in productivity across labour markets and if these differences are no longer equalised either through a collective bargaining system or by social policy programs.

An important part of the Nordic model is the established and wellfunctioning collective bargaining system. The role of social partners, employer federations and trade unions reflects a high degree of institutional trust, which has been crucial in the construction of social policy programmes. There has been a cross-class alliance behind many of the core welfare reforms and both the employee and employer organisations participated in these mutual pacts. The collective bargaining system has promoted solidarity through broad-based wage agreements where low-productivity and female-dominated sectors have gained at the expense of male-dominated export industry sectors. ${ }^{12}$

Labour union membership has declined in Nordic countries with new forms of contracted work and other types of non-standard employment contracts. It is quite likely that technological change will bring about and promote new forms of employment such as micro-jobs with very short durations, self-employment and outsourcing. That may, in turn, weaken the role of labour unions and reduce their influence in policy-making. The downside is that the weakest members of the labour force might not be able to collectively defend their interests. That may not only reduce institutional trust endowed in a collective bargaining system but also have a negative effect more generally on social trust.

Social trust is also important for the development of remedies against possible disruptions in the labour market. If we implement, for example, universal basic income as a safeguard against the risks of automation and give government grants with no strings attached to the people, it should be a sign of and be 
based on trust. In turn, the recipients' trust in society is reinforced by the fact that society is prepared to entrust them to use the money for good purposes. The relationship between society and the recipients is thus based on reciprocal trust.

\section{Human capital investment}

Today, perhaps more than ever before, a nation's economic success is dependent on its human capital and innovations. The Nordic social investment strategy recognises the inputs or social investment policies and the outputs or the returns of social investment policies. The endeavour to establish universal access to education was a prominent feature in the conception of the education systems of the Nordic countries and grassroots level educational systems were harnessed to accomplish the task. Comprehensive schools were directed to provide the same basic education for all. ${ }^{13}$

With the emergence of the knowledge-based economy, the focal points of public policies are cognitive and non-cognitive skills developed in early childhood according to James Heckman and Dimitriy V. Masterov. In early childhood, publicly provided child day care and preschool education make up an important part of the social investment, as succeeding policies rest on the cognitive skills learned in these formative years. Early childhood education and care (ECEC) involves elements of both physical care and education (socialisation as well as cognitive stimulation). Though the comprehensiveness and levels vary, all Western European countries have direct income transfers to families with children, but few other countries have as extensive ECEC policies for families with children as the Nordic countries do, as illustrated by Hiilamo and Kangas. Sweden and Denmark have the highest share of children (from birth to two years old) in public day care. The share is the lowest in Finland despite the fact that there is a day care guarantee. The reason is a cash-for-care programme (CFC) called the 'child home care allowance'. ${ }^{14}$

Cash-for-care programmes are relatively low, flat-rate benefits paid to parents after paid parental leave. The benefits do not fully compensate for wage losses; hence they are fundamentally different from the paid parental leave payments. These benefits may impede access to the labour market for mothers with small children and hamper their ability to adapt to changes in the labour market. The first CFC was enacted in Finland in 1985 in order to offer alternative support to families who did not take advantage of ECEC services while their youngest child was under the age of three. The scheme is an important part of Finnish care policies. More than 50 per cent of eligible mothers receive CFC. Mothers with lower education levels are overrepresented among the recipients. According to Guðný Björk Eydal et al., a similar scheme was enacted in Norway in 1998, but participation has gradually decreased. In Sweden, the idea of CFC has been highly contentious politically. In Sweden, a CFC scheme has been enacted twice, in 1994-1995 and 2008-2016, but in 2016 a new centre-left government decided to abolish the legislation. In Denmark, it is possible to 


\section{2}

receive CFC, but it is used by very few parents, since the Danish care policies emphasise ECEC services for children from the age of one year. In Iceland, CFC has not been legislated. ${ }^{15}$

The dynamic nature of the social investment strategy entails that skills acquired in one stage of life should provide the foundation for the formation of further skills or their use in the next stage of life. Early cognitive skills establish the foundation for learning throughout a person's life. This is ever more important with the view of expected need to adopt new skills and tasks in the future. The cognitive and formal qualifications acquired during childhood and youth are intended to meet the skill demands of the labour market, where returns are also given a monetary form in terms of revenue to the exchequer and various insurance and saving schemes. Even now, the CFC system poses a considerable risk to Nordic mothers lacking higher education who are stuck long-term with a low-level benefit without contact to labour markets. There is evidence that choosing CFC instead of ECEC will lead to poorer educational outcomes for Finnish children and for Norwegian children. ${ }^{16}$ This risk will be aggravated if technological change increases uncertainty in the labour markets.

The reforms in Nordic school systems were accomplished by involving schools in the realisation of social goals such as equal opportunity and community fellowship. The Nordic vision of child education is that children from less privileged backgrounds should be enabled to receive an education on par with children from more privileged backgrounds. As Eva Österbacka shows, the educational system is crucial for explaining to what degree the parental background is inherited. Students' performance in the Nordic countries is less dependent upon family background than in most other countries. ${ }^{17}$ Maintaining educational equality is a challenging task given the important role of private schools in Denmark and the effects of the Swedish liberalisations of the 1990s, which facilitated the foundation of private schools and encouraged students to actively choose schools, thereby concentrating students from educated families to the schools with the best reputations. In contrast, the private school system plays a minor role in Finland and Norway. Technological change may require more fiscal inputs as well as policy reforms in the future to guarantee equal opportunity in education.

\section{The NEET debate}

The quest for social investment can be also expressed by a shift from decommodification to recommodification, as Natalie Morel et al. point out. According to K. Albæk et al., the shift is particularly important for young people, as research indicates that unemployment has a 'scarring effect' and affects future labour market opportunities. For technical reasons, Nordic youth unemployment figures include large numbers of students who, besides studying, are also looking for work. Youth unemployment rates are much higher in Finland and Sweden than they are in Norway and Denmark, a difference which may be 
largely explained by how pupils in the school-based vocational training systems in Sweden and Finland are classified as outside the labour force, or as unemployed if they are looking for a job, whilst apprentices in the apprenticeshipbased vocational training systems in Norway and Denmark are classified as employed. For this reason, NEET rates, that is young people between the ages of 18 and 24 who are not employed, or in education or training programmes, can be posited as a more relevant indicator of youth disengagement. ${ }^{18}$

Nearly all young people start upper-secondary educations in the Nordic countries in academic or vocational tracks. According to the OECD, ${ }^{19}$ a significant proportion of Nordic students do not complete upper-secondary education, and large proportions of these young people are in NEET situations for certain periods of time. The situation is clearly worst in Finland. In all Nordic countries besides Iceland, boys are far more likely to experience NEET status than girls. Young people, and especially young men, in vocational tracks are overrepresented among those who do not complete their three- or four-year courses within five years. The worryingly high non-completion rates are often attributed to the fact that young people have not acquired basic skills in reading, writing and mathematics in primary education. This problem is expected to worsen with digitalisation if new policies are not implemented.

The discourse on NEET young people in the Nordic countries is closely tied to the welfare state orientation. As the OECD shows, low birth rates and ageing populations are shifting the dependency ratios of young and older adults to people of working age across the Nordic countries. As a consequence, the long-term sustainability of the welfare state is under pressure and the importance of integrating young people into the labour markets should be emphasised. The consensus is that young people with education should be employed as quickly as possible and that those without education should start toward one as soon as possible - provided they are able to do so. Against this backdrop, young people who are neither working nor participating in education or training are perceived as a problem, as neither contributing to the welfare state in the present nor gaining qualifications and experience to contribute in the future. $^{20}$

The NEET young people are a heterogeneous group with a variety of subgroups such as young people with low levels of education, young people whose parents have low levels of education, and those with an immigrant background. The NEET young people face a heightened risk of falling outside the labour market and 'society' the longer their NEET status lasts. This implies that increased likelihood of future social exclusion, rather than the ongoing situation, is the most important problem for NEET young people. However, it is important to note that the future-orientation and probabilistic conceptualisations in this type of youth research do not necessarily correspond well with the experiences of the people it concerns. In any case, there is an urgent need to develop policies to reduce the number of long-term NEET young people. This emphasis will be heightened should technological change increase 
unemployment more among less educated youth as a number of scholars have predicted. $^{21}$

\section{Labour markets}

In the beginning of the 1990s, Denmark implemented a series of labour market reforms denoting a shift from passive to active labour market policies. These policies were later coined as 'flexicurity' and gave Denmark a reputation of being a forerunner among all the OECD countries in tackling unemployment among those at the margins of the labour market. While departing from the original ideas of the Nordic model, the Danish reforms tightened the eligibility for unemployment benefits, decreased benefit periods, and introduced workfare elements into unemployment insurances and other social policies. The reforms were legitimised by emphasising reciprocity between the citizens and society. This was called a 'right and duty principle'. The reasoning was that individuals had a right to income support as long as they were willing to work and actively searched for jobs. In return, society was obliged to assist jobseekers in improving their job prospects. The reform labour market regulation was dismantled making it easier to 'fire and hire', which became the trademark of the Danish model that gained international recognition. Other Nordic countries have followed suit, but to a lesser degree. ${ }^{22}$

In terms of labour market institutions, the Nordic countries are classified among the so-called coordinated market economy countries as opposed to liberal market economy countries. ${ }^{23}$ This is the model in which production is more coordinated than in the liberal market model: employers and labour unions are both represented in collective bargaining organisations and education provides vocational and skills-based training rather than general education, and has guaranteed historically more stable employment careers. Nordic labour market institutions encourage long-term employment through comprehensive employment protection legislation. With the exception of Denmark, the Nordic labour market institutions with a high degree of inertia might not allow easy and quick adoption of policies to tackle major changes. ${ }^{24}$

According to M. R. Busemeyer, in the wake of technological change, the types of skills workers possess may determine their range of exit options as much as their general education levels. M. Estevez-Abe et al. claim that workers in the Nordic coordinated market regimes may be less mobile across different occupations relative to workers in liberal market regimes. For these reasons technological change would arguably have a substantial impact on workers' employment prospects and economic security in the Nordic countries where workers have vocational and skills-based training with the least cross-occupational mobility, at least in the short-term since the learning and updating of skills takes time. ${ }^{25}$

As part of the project to ensure full employment and comprehensive utilisation of talents, the Nordic welfare state model has certainly helped women to enter the labour market. The policies also appear to have lowered the income 
differentials between males and females. However, gender relations are perhaps not as equal as they seem at first glance. ${ }^{26}$ The other side of the coin is that Nordic women are predominantly working in the welfare sector, which leads to a high degree of occupational segregation by gender. This occupational segregation has a triple effect upon gender equality. Firstly, women may be stuck low-paying public-sector occupations. Secondly, their representation in highpaying occupations may be lower than in countries with smaller public sectors. Thirdly, women are overrepresented in part-time jobs that may be more easily replaced when technological change takes place. Were technological change to hit the public service sector hard, it would harm gender equality and increase the gender pay gap. However, on average, females have higher educational attainment than males. Currently, public-sector workers are more likely to be cushioned from the displacement effects of technological change than private sector workers, but the situation might change if the public service outsourcing trend continues. ${ }^{27}$

Critics of the Nordic model claim that providing generous benefits destroys incentives to work. Also, within the Nordic area, there are vociferous political calls for income inequality in order to increase the incentives for work and thereby enhance economic growth. Empirical findings suggest it is very hard to empirically justify social inequalities by referring to their beneficial effects on employment and economic growth. ${ }^{28}$ However, it is still an open question if earning-related unemployment benefits with high replacement rates, typical in Nordic countries, lock in unemployed workers who previously worked in sunset industries.

The deep economic crisis in the 1990s showed that the universal and advanced Nordic welfare states were able to absorb macro-economic shocks and stabilise living conditions when needed. Despite skyrocketing unemployment and rising income differences, differences in disposable incomes and poverty did not change that dramatically. Imagine what could happen in another welfare state if within a three year period unemployment rose from 4 to 18 per cent and the GDP fell by 13 per cent as was the case in Finland between 1991 and $1993 .{ }^{29}$ With the previously proven antidotes, the Nordic labour markets rebounded quite well after the global economic crises in 2008. The scenario could be different if technological change induced a continuous decline in paid employment.

Migration also needs to be considered in analysing the effect of technological change on the Nordic model. Migrants, especially women, have generally lower labour market participation rates, in part, due to the skill composition of migrants entering advanced West European economies. Much of the recent active labour market policies in the Nordic countries have aimed at integrating such groups into the labour market. ${ }^{30}$

Increasing ethnic diversity does not constitute a threat to the Nordic welfare state as such, but given the high level of unemployment among immigrants, the in-group and out-group distinction has already started to play a greater role (most notably in Denmark). As shown by W. van Oorschot, in all European 
countries people perceive immigrants as less deserving than, for example, the unemployed. ${ }^{31}$ The nationalist-populist parties using anti-immigration banderols are receiving a substantial share of votes in the Nordic countries by claiming that the universal, generous benefits will attract people from other countries interested in such benefits. In Finland, unemployment protection for migrants was weakened in 2016.

Ideally, there should be no wedge between the well-off payers and the worseoff beneficiaries in the Nordic model. As Nelson highlights, there would be no room for 'welfare backlash', since everybody contributes to and everybody benefits from the system. However, the in-group and out-group distinction and related political debates might become even more destructive if the technological change increases unemployment among less educated populations who are more likely to vote for populist parties. ${ }^{32}$

The rise of populist parties has coincided with decreased support for Social Democratic parties to whose political ambitions the Nordic model is sometimes attributed to. The Nordic policies are generally not the result of particular political movements, but rather endorsed by a wide spectrum within the political field. ${ }^{33}$ However, party-based political division on migration issues might undermine universalism, which is one of the most important trademarks of the Nordic welfare state. In principle, social and health benefits are for all. They are neither targeted to the needs of some specific vulnerable groups, nor are they exclusive benefits for privileged occupational groups or immigrant populations. At the core of universalism is a sense of commonality; it is an expression of human rights.

The pension policies in the Nordic countries have aimed to increase participation of aged workers, for example, through built-in incentives to delay labour market exit and part-time pension schemes. In the wake of automation, these policies may prove insufficient if older workers are also required to quickly learn new skills and adapt to new modes of work.

\section{Basic income debate}

Societal disruptions create windows of opportunity. After the economic collapse of 2008, new radical ideas were emerging and were considered more realistic because the context had changed suddenly and completely. Universal basic income as a solution to expected uncertainties in the labour market has gained traction in a number of countries. Also, politicians and business elites have taken an interest in basic income. As a result, a number of countries have embarked on experiments with basic income. Between 2017 and 2018, the Finnish state ran an experiment with basic income. There are ongoing, planned and interrupted basic income experiments in also in Kenya, the Netherlands, Canada, Scotland, Uganda, and the United States. ${ }^{34}$

In the 1970s, the concept of basic income gathered interest from legislators and governments in the United States and Canada resulting in local experiments. ${ }^{35}$ The four negative income tax experiments in five US states between 
1968 and 1980 and in the Canadian province of Manitoba between 1974 and 1979 were deemed a success in terms of informing the decision-makers on the effects of experimental interventions but disappointing for the basic income advocates. In the 1970s and 1980s, basic income was debated in Sweden as a response to ideas put forward by scholars such as Milton Friedman and André Gorz as well as experiments conducted in the United States and Canada. Later, both Swedish and Danish debates focused on freedom from work and criticised the full employment ideology. However, among the Nordic countries, only Finland has shown more than academic interest in the topic. ${ }^{36}$

Since the mid-1990s, Finnish public discourse promoted the idea of a short form of workfare coined as 'activation' with the catch phrase 'work is the best social security'. The policies emphasised unemployed persons' skills and motivation and they justify activation through reciprocity, making participation in activation measures a norm and a moral responsibility. In 2001, the Rehabilitative Work Act was introduced as an effort to re-integrate the long-term unemployed into the labour market and to improve their life management skills through forced employment. ${ }^{37}$

The Finnish basic income experiment was based on a completely different ideology. In this experiment, a randomly selected group of two thousand unemployed Finns were paid $€ 560$ per month for a study period of two years regardless of employment status, a much different system than Finland and neighbouring countries had been used to. The preliminary results released in 2019 by the Ministry of Social Affairs and Health indicate no positive employment effects in the experiment group. The final results of the experiment released in 2020 pointed to the same direction. Early government responses signal that basic income will not become mainstream in reforming social security in Finland. ${ }^{38}$

Workfare policies otherwise applied in Finland as well as in other Nordic and Western countries focus on conditionality. Should there be conditions for benefits or can we trust people and just give them money? In exchange for access to benefits, there are conditions as well as social services such as training programmes, job-seeking assistance, or other care services. There is a fear that if there are no conditions, people will just run away and turn their backs on society. Social workers will be left with no way of providing support in their professional capacities. The new set of policies to support those in the margins of the labour market needs to find a balance between employment promotion services and income guarantee programmes.

\section{Conclusions}

The sustainability of the Nordic model requires that the Nordic countries quickly adopt new technology to compete in global markets. Highly developed public institutions demand a high rate of employment and a reasonably high level of taxes. The question of technologically induced unemployment is of paramount interest for the fiscal sustainability of the Nordic model. 
Social trust is undeniably an important element in the development of remedies against possible disruptions in the labour market. This means that there is a two-way connection between successful employment outcomes and strong public institutions. A high rate of employment with a considerably high rate of taxation is needed to support and develop public institutions, while strong public institutions with emphasis on early-life social investments are needed to support employment outcomes.

With new forms of contracted work and other types of non-standard employment contracts, such as micro-jobs, labour union membership has declined in the Nordic countries. That may not only weaken the role of labour unions in policy-making but also reduce institutional trust endowed in collective bargaining. If any country were to implement, for example, universal basic income as a safeguard against the risks of automation, it should be a sign of social trust in the individual.

Ensuring gender equality in the labour market in the wake of automation calls for education and employment policies that would reduce occupational segregation by gender. There is also an ever more important argument for a stronger role of the state in guaranteeing employment among those who are vulnerable to employment shocks created by technological change. Possible areas for supported employment include education and care where human labour is more difficult to replace with machines. There is also an urgent need to develop policies to reduce the number of long-term NEET young people.

The comprehensive Nordic welfare state policies are responsible for the equal social outcomes in the Nordic countries. Generally they have been endorsed by a large spectrum of the political field. However, party-based political division on migration issues and emergency of discriminatory policies against migrants may undermine universalism, which is one of the most important trademarks of the Nordic welfare state.

\section{Notes}

1 Acemoglu \& Robinson 2012, Andersen et al. 2007, Hiilamo, Merikukka \& Haataja 2018, Kvist, Fritzell, Hvinden \& Kangas 2012.

2 Frey \& Osborne 2013, 2017.

3 Pulkka 2018.

4 Arntz, Gregory \& Zierahn 2016.

5 Acemoglu \& Restrepo 2018, 13.

6 Pulkka 2018.

7 Katzenstein 1985.

8 Kvist, Fritzell, Hvinden \& Kangas 2012.

9 Fukuyama 1995, Hiilamo et al. 2013, 16.

10 Putnam 2000.

11 Flora 1984.

12 Swenson 2002.

13 Denmark still has folkeskole, though.

14 Hiilamo \& Kangas 2009. 
15 Hiilamo \& Kangas 2009, Giuliani \& Duvander 2017, Eydal, Rostgaard \& Hiilamo 2019.

16 Karhula, Erola \& Kilpi-Jakonen 2017, Hiilamo, Merikukka \& Haataja 2018, Kosonen \& Huttunen 2018. On Norwegian children, see Havnes \& Mogstad 2011.

17 Österbacka 2004. See also Telhaug, Medias \& Aasen, Petter 2006.

18 Bäckman et al. 2011, Holte, Swart \& Hiilamo 2018.

19 OECD 2017.

20 Holte, Swart \& Hiilamo 2018.

21 Albæk et al. 2015, Halvorsen, Hansen \& Tägström 2012, Frey \& Osborne 2013, 2017, Autor 2015, Arntz, Gregory \& Zierahn 2016.

22 Hiilamo \& Komp 2018, Oorschot 2006.

23 See e.g. Soskice 1999.

24 Soskice 1999.

25 Estevez-Abe, Iversen \& Soskice 2001, Busemeyer 2014.

26 Hiilamo \& Kangas 2009.

27 Mandel \& Semyenov 2006, Datta-Gupta, Smith \& Verner 2008.

28 Heinrich 2003, Kenworthy 2004.

29 Kiander \& Vartia 2011.

30 Hiilamo et al. 2013.

31 Oorschot 2006.

32 Nelson 2003.

33 Hiilamo \& Kangas 2009.

34 McFarland 2017.

35 See Hum \& Simpson 2001.

36 Perkiö 2019.

37 Hiilamo \& Komp 2018.

38 De Wispeleare, Halmetoja \& Pulkka 2018.

\section{References}

Acemoglu, Daron \& Restrepo, Pascual, 2018: “The Race between Man and Machine: Implications of Technology for Growth, Factor Shares, and Employment" in American Economic Review, 108:6, 1488-1542.

Acemoglu, Daron \& Robinson, James, 2012: Why Nations Fail: The Origins of Power, Prosperity and Poverty. London: Profile Books.

Albæk, Karsten, Asplund, Rita, Barth, Erling, Lindahl, Lena \& Simson von, Kristine, 2015: "Ungdomsarbeidsløshet i Norden [Youth Unemployment in Nordic Europe]. in Søkelys på arbeidslivet, 31:1-2, 78-90.

Andersen, Torben, Holmström, Bengt, Honkapohja, Seppo, Korkman, Sixten, Söderström, Hans Tson \& Vartiainen, Juhana, 2007: The Nordic Model: Embracing Globalization and Sharing Risks. Helsinki: The Research Institute of the Finnish Economy (ETLA).

Arntz, Michael, Gregory, Thomas \& Zierahn, Ulrich, 2016: The Risk of Automation for Jobs in OECD Countries: A Comparative Analysis. Working Papers No. 189. Paris: OECD Social, Employment and Migration, OECD Publishing.

Autor, David, 2015: "Why are There Still So Many Jobs? The History and Future of Workplace Automation" in Journal of Economic Perspectives, 29:3, 3-30.

Bäckman, Olof, Jakobsen, Vibeke, Lorentzen, Thomas, Österbacka Eva \& Dahl, Espen, 2011: Dropping Out in Scandinavia: Social Exclusion and Labour Market Attachment among Upper Secondary School Dropouts in Denmark, Finland, Norway and Sweden. Working Paper 2011:8. Stockholm: Institute for Future Studies. 
Busemeyer, Marius, 2014: Skills and Inequality: Partisan Politics and the Political Economy of Education Reforms in Western Welfare States. Cambridge: Cambridge University Press.

Datta-Gupta, Nabanita, Smith, Nina \& Verner, Mette, 2008: "The Impact of Nordic Countries' Family Friendly Policies on Employment, Wages \& Children" in Review of the Economics of the Household, 6:1, 65-89.

De Wispeleare, Jürgen, Halmetoja, Antti \& Pulkka, Ville-Veikko, 2018: “The Finnish Basic Income Experiment - Correcting the Narrative" in Social Europe, 8 November 2018. www.socialeurope.eu/the-finnish-basic-income-experiment-correcting-the-narrative.

Estevez-Abe, Margarita, Iversen, Torben \& Soskice, David, 2001: "Social Protection and the Formation of Skills: A Reinterpretation of the Welfare State: Varieties of Capitalism: The Institutional Foundations of Comparative Advantage" in David Soskice \& Peter Hall (eds.) Varieties of Capitalism: The Institutional Foundations of Comparative Advantage. Oxford: Oxford University Press, 145-183.

Eydal, Guðný Björk, Rostgaard, Tine \& Hiilamo, Heikki, 2019: "Family Policies in the Nordic Countries: Aiming at Equality" in Guðný Björk Eydal \& Tine Rostgaard (eds.) Handbook of Family Policy. Cheltenham: Edward Elgar Publishing, 195-208.

Flora, Peter (ed.) 1984: Growth to Limits (vol. 1). Berlin: de Gruyter.

Frey, Carl \& Osborne, Michael, 2013: "The Future of Employment: How Susceptible are Jobs to Computerisation?" 17 September 2013. Archived by Archive.org.

Frey, Carl \& Osborne, Michael, 2017: “The Future of Employment: How Susceptible are Jobs to Computerisation?" in Technological Forecasting and Social Change, 114:C, 254-280.

Fukuyama, Francis, 1995: Trust: The Social Virtues and the Creation of Prosperity. London: Penguin Books.

Giuliani, Giuliani \& Duvander, Ann-Zofie, 2017: "Cash-for-Care Policy in Sweden: An Appraisal of Its Consequences on Female Employment" in International Journal of Social Welfare, 26:1, 49-62.

Halvorsen, Björn, Hansen, Ole-Johnny \& Tägström, Jenny, 2012: Unge på Kanten: Om inkludering av utsatte ungdommer [Young People on the Edge: Labour Market Inclusion of Vulnerable Youths]. Nord 2012:005. Copenhagen: Nordic Council of Ministers.

Havnes, Tarjei \& Mogstad, Magne, 2011: "No Child Left Behind: Subsidized Child Care and Children's Long-Run Outcomes" in American Economic Journal: Economic Policy, 3:2, 97-129.

Heinrich, Georges, 2003: "More is Not Necessarily Better: An Empirical Analysis of the Inequality - Growth Tradeoff Using the Luxembourg Income Study" in Luxembourg Income Study. Working Papers 344. Luxembourg: LIS.

Hiilamo, Heikki \& Kangas, Olli, 2009: "Trap for Women or Freedom to Choose? The Struggle Over Cash for Child Care Schemes in Finland and Sweden" in Journal of Social Policy, 38:3, 457-475.

Hiilamo, Heikki, Kangas, Olli, Fritzell, Johan, Kvist, Jon \& Palme, Joakim, 2013: Recipe for a Better Life: Experiences from the Nordic Countries. Helsinki: CMI Martti Ahtisaari Centre.

Hiilamo, Heikki \& Komp, Kathrin, 2018: “The Case for a Participation Income: Acknowledging and Valuing the Diversity of Social Participation" in The Political Quarterly, 89:2, 256-261. https://doi.org/10.1111/1467-923X.12511.

Hiilamo, Heikki, Merikukka, Marko \& Haataja, Anita, 2018: "Long-Term Educational Outcomes of Child Care Arrangements in Finland" in SAGE Open, 8:2. https://doi. org/10.1177/2158244018774823.

Holte, Bjørn Hallstein, Swart, Ignatius \& Hiilamo, Heikki, 2018: "The NEET Concept in Comparative Youth Research: The Nordic Countries and South Africa" in Journal of Youth Studies, 22:2, 256-272. https://doi.org/10.1080/13676261.2018.1496406. 
Hum, Derek \& Simpson, Wayne, 2001: “A Guaranteed Annual Income: From Income to the Millennium" in Policy Options, 22:1, 78-82.

Karhula, Aleksi, Erola, Jani \& Kilpi-Jakonen, Elina, 2017: "Home Sweet Home? LongTerm Educational Out-Comes of Childcare Arrangements in Finland" in Hans-Peter Blossfeld, Nevena Kulic, Jan Skopek \& Moris Triventi (eds.) Childcare, Early Education and Social Inequality: A Cross-National Perspective. Cheltenham: Edward Elgar Publishing, 268-285.

Katzenstein, Peter, 1985: Small States in World Markets: Industrial Policy in Europe. Ithaca, NY: Cornell University Press.

Kenworthy, Lee, 2004: "Welfare States, Real Income and Poverty" in Luxembourg Income Study. Working Papers 370. Luxembourg: LIS.

Kiander, Jaakko \& Vartia, Pertti, 2011: "Lessons from the Crisis in Finland and Sweden in the 1990s" in Empirica, 38:1, 53-69.

Kosonen, Tuomas \& Huttunen, Kristiina, 2018: Kotihoidon tuen vaikutus lapsiin. Tutkimuksia 115. Helsinki: Palkansaajien tutkimuslaitos.

Kvist, Jon, Fritzell, Johan, Hvinden, Björn \& Kangas, Olli (eds.) 2012: Changing Social Equality: The Nordic Welfare Model in the 21st Century. Bristol: Policy Press.

Mandel, Hadas \& Semyenov, Moshe, 2006: “A Welfare State Paradox: State Interventions and Women's Employment Opportunities in 22 Countries" in American Journal of Sociology, 111:6, 1910-1949.

McFarland, Kate, 2017: Current Basic Income Experiments (and Those So Called): An Overview. Updated 19 October 2017. https://basicincome.org/news/2017/10/overview-ofcurrent-basic-income-related-experiments-october-2017/ [Accessed 10 October 2018].

Nelson, Kenneth, 2003: Fighting Poverty: Comparative Studies on Social Insurance, Means-Tested Benefits and Income Redistribution. Stockholm: Swedish Institute for Social Research.

OECD, 2017: Education at a Glance 2017. OECD Indicators. Paris: OECD Publishing.

Oorschot, Wim, van, 2006: "Making the Difference in Social Europe: Deservingness Perceptions among Citizens of European Welfare States" in Journal of European Social Policy, 16:1, 23-42. https://doi.org/10.1177/0958928706059829.

Österbacka, Eva, 2004: It Runs in the Family: Empirical Analyses of Family Background and Economic Status. Åbo: Åbo Akademi University Press.

Perkiö, Johanna, 2019: "From Rights to Activation: The Evolution of the Idea of Basic Income in the Finnish Political Debate, 1980-2016" in Journal of Social Policy [published online ahead of print], 1-17. https://doi.org/10.1017/S0047279418000867.

Pulkka, Ville-Veikko, 2018: "This Time May Be a Little Different: Exploring the Finnish View on the Future of Work" in International Journal of Sociology and Social Policy, 39:1-2, 22-37. https://doi.org/10.1108/IJSSP-05-2018-0070.

Putnam, Robert, 2000: Bowling Alone: The Collapse and Revival of American Community. New York: Simon \& Schuster.

Soskice, David, 1999: "Divergent Production Regimes: Coordinated and Uncoordinated Market Economies in the 1980s and 1990s" in Herbert Kitschelt, Peter Lange, Gary Marks \& John D. Stephens (eds.) Continuity and Change in Contemporary Capitalism. Cambridge Studies in Comparative Politics. Cambridge: Cambridge University Press, 101-134.

Swenson, Peter, 2002: Capitalist Against Markets: The Making of Labor Markets and Welfare States in the United States and Sweden. Oxford: Oxford University Press.

Telhaug, Alfred, Medias, Asbjörn \& Aasen, Petter, 2006: “The Nordic Model in Education: Education as Part of the Political System in the Last 50 Years" in Scandinavian Journal of Educational Research, 50:3, 245-283. 